\title{
Impact of COVID-19 on dermatology practice. Comments from Jordan
}

\section{Wpływ pandemii COVID-I 9 na praktykę dermatologiczną. Komentarz z Jordanii}

\author{
Khaled Seetan', Rami Al Omari² \\ 'Department of Clinical Dermatology, Faculty of Medicine, Yarmouk University, Irbid, Jordan \\ ${ }^{2}$ Department of Ophthalmology, Faculty of Medicine, Yarmouk University, Irbid, Jordan \\ Dermatol Rev/Przegl Dermatol 2021, 108, 236-238 \\ DOI: https://doi.org// 0.5 I|4/dr.2021. 108605
}

COVID-19 is a disease first reported in $\mathrm{Wu}$ han, China as pneumonia of unknown cause, then later it was revealed that this disease is caused by a new type of coronavirus, an enveloped polymorphic RNA virus [1]. This outbreak was declared on February 11, 2020 as an international public health emergency by the World Health Organization (WHO) [1]. Dermatology practices have been affected by this pandemic, including the effects of personal protective equipment, concerns of safe practice during this pandemic, and interactions of dermatological treatment with COVID-19. Chen et al. reported that the dermatology outpatient department at West China Hospital of Sichuan University was shut temporarily in January 2020, as all elective operations were postponed allowing only emergency ones, and scheduled to run at January, 28,2020 , and during this period, they provided free consultations online and via telephone, and even after the re-opening of the outpatient department [2]. In the United States, a study revealed that during a period of one month between February and March of 2020, dermatology practice days were reduced from 4.2 to 3.1 , and the average number of patients from 149.4 to 63.3. Additionally, postponing non-important visits increased from $35.5 \%$ to $79.4 \%$ [3].

COVID-19 can present with various cutaneous symptoms. These include covid fingers, urticarial reactions, chickenpox-like vesicles, erythematous rash, disseminated intravascular coagulation and aggravation of pre-existing conditions [4].

Skin damage induced by the PPE is common among medical staff due to prolonged periods of equipment wearing and frequent hand sanitization. Lan et al. stated that the prevalence of skin damage among frontline healthcare workers due to PPE was $97 \%$, affecting the nasal bridge, hands,
COVID-19 jest chorobą, którą wykryto po raz pierwszy w chińskim mieście Wuhan i opisano jako zapalenie płuc o nieznanej przyczynie. Ustalono, że schorzenie jest wywoływane przez nowy typ polimorficznego osłonkowego wirusa RNA należącego do grupy koronawirusów [1]. 11 lutego 2020 roku Światowa Organizacja Zdrowia (World Health Organization - WHO) ogłosiła stan zagrożenia dla zdrowia publicznego o zasięgu międzynarodowym w związku z rozprzestrzenianiem się choroby [1]. Jednym z obszarów w systemie opieki zdrowotnej, na które oddziałuje pandemia COVID-19, jest dermatologia. Ma to związek między innymi ze skutkami stosowania środków ochrony indywidualnej, obawami dotyczącymi bezpieczeństwa praktyki zawodowej lekarzy dermatologów oraz potencjalnymi interakcjami między terapią dermatologiczną i COVID-19. W pracy Chen i wsp. podano, że poradnia i oddział dermatologiczny w szpitalu klinicznym West China Hospital of Sichuan University w Chinach zostały tymczasowo zamknięte 24 stycznia 2020 roku. Wszystkie planowe zabiegi przełożono, a dopuszczono jedynie wykonywanie zabiegów ze wskazań nagłych. Działanie poradni wznowiono 28 stycznia 2020 roku, jednocześnie uruchamiając system bezpłatnych konsultacji internetowych [2]. W badaniu przeprowadzonym w Stanach Zjednoczonych ustalono, że na przełomie lutego i marca 2020 roku liczba dni pracy lekarzy w poradni dermatologicznej zmniejszyła się z 4,2 do 3,1 w tygodniu, natomiast średnia liczba przyjmowanych pacjentów zmniejszyła się z 149,4 do 63,3. Odnotowano również wzrost odsetka odwoływanych wizyt z 35,5\% do 79,4\% [3].

COVID-19 może indukować różne zmiany skórne. Mogą to być m.in.: palce covidowe, reakcje pokrzywkowe, zmiany pęcherzykowe przypominające ospę wietrzną, wysypka rumieniowa, objawy rozsianego wykrzepiania wewnątrznaczyniowego, a także zaostrzenie wcześniej istniejących schorzeń [4]. 
cheeks, and forehead. Wearing face shields was not associated with increased incidence of skin damage [5]. Furthermore, Yan et al. reported that twothirds of the Chinese frontline healthcare workers had hyperhidrosis due to wearing tight masks and goggles, in addition to facial itching, acne aggravation, delayed pressure urticaria and facial inflammatory papules. Besides, maceration, erosions, and increased risk of hand eczema were noted in medical personnel due to prolonged use of gloves, frequent hand hygiene, alkaline soap usage, and use of hot water, so hands should be clean and dry before wearing $[5,6]$. Hand dermatitis can be controlled by using moisturizer and barrier creams in addition to wearing latex-free gloves [7].

The immunological response to COVID-19 includes increased production of many cytokines which play a role in the pathogenesis of this disease. During this pandemic, the use of immunosuppressant and immuno-biological therapy for dermatological patients is an area of question, especially because modulation of cytokines' effects is believed to have a role in the prevention of lung damage in viral infections, which is why the efficacy and safety of some immuno-biological agents such as tocilizumab are under study for the treatment of COVID-19 [8]. There is little evidence off whether to discontinue, reduce the dose or continue the use of immunosuppressant agents. For example, cyclosporine and methotrexate are suggested not to be stopped to avoid exacerbation of the dermatological condition [9]. In case of current COVID-19 infection, the decision of stopping or continuing the therapy should be taken on a caseby-case basis balancing the risks and benefits of this decision [9].

Although there is no evidence associating COVID-19 complications with the use of systemic cancer therapy, patients who are on ICIs should be monitored regularly, with some studies even suggesting delaying the treatment with ICIs for patients who are showing COVID-19 symptoms [8].

\section{CONFLICT OF INTEREST}

The authors declare no conflict of interest.
Wśród personelu medycznego powszechne są zmiany skórne wywoływane przez długie stosowanie środków ochrony indywidualnej oraz częste dezynfekowanie rąk. Według Lan i wsp. zmiany skórne spowodowane przez środki ochrony indywidualnej występują aż u 97\% personelu medycznego pracującego z pacjentami z COVID-19. Zmiany są najczęściej zlokalizowane na skórze grzbietu nosa, policzkach i rękach. Nie stwierdzono zależności między stosowaniem przyłbic ochronnych i zwiększoną częstością występowania zmian skórnych [5]. Yan i wsp. wskazują, że u 2/3 chińskich pracowników medycznych pracujących z pacjentami z COVID-19 występuje nadmierne pocenie spowodowane noszeniem ciasnych masek i okularów ochronnych. Obserwowany jest również świąd skóry twarzy, nasilenie zmian trądzikowych, pokrzywka opóźniona z ucisku oraz grudkowe wykwity zapalne na twarzy. U personelu medycznego stwierdza się też macerację skóry, nadżerki oraz podwyższone ryzyko wyprysku rąk związane z długotrwałym noszeniem rękawiczek ochronnych, częstym myciem i dezynfekcją rąk oraz stosowaniem mydła o odczynie alkalicznym i gorącej wody $[5,6]$. W ramach profilaktyki zmian skórnych rąk należy używać kremów nawilżających i ochronnych, stosować bezlateksowe rękawiczki ochronne [7].

Odpowiedź immunologiczna na COVID-19 obejmuje wzmożoną produkcję licznych cytokin, które mają znaczenie $\mathrm{w}$ patogenezie tej choroby. $\mathrm{W}$ warunkach pandemii nierozstrzygniętą kwestią jest stosowanie terapii immunosupresyjnej i immunobiologicznej u pacjentów ze schorzeniami dermatologicznymi. Uważa się, że modulacja działania cytokin przyczynia się do zapobiegania uszkodzeniom płuc w przebiegu zakażeń wirusowych. Z tego względu skuteczność i bezpieczeństwo niektórych leków immunobiologicznych, między innymi tocilizumabu, są badane pod kątem leczenia COVID-19 [8]. Dostępnych jest niewiele danych, które pozwoliłyby sformułować zalecenia dotyczące stosowania przez pacjentów leków immunosupresyjnych, tj. kontynuacji ich przyjmowania, przerwania bądź zmniejszenia dawkowania. Wskazuje się na przykład, aby nie odstawiać leczenia cyklosporyną i metotreksatem ze względu na ryzyko zaostrzenia schorzenia dermatologicznego [9]. W sytuacji zakażenia COVID-19 decyzja o przerwaniu albo kontynuowaniu terapii powinna być podejmowana indywidualnie w każdym przypadku, na podstawie analizy ryzyka i korzyści [9].

Mimo że nie ma dowodów na zależność między powikłaniami COVID-19 i stosowaniem ogólnej terapii przeciwnowotworowej (immune checkpoint inhibitors - ICI), a chorzy leczeni ICI powinni być na bieżąco monitorowani. Niektóre badania sugerują nawet opóźnienie leczenia ICI u pacjentów z objawami COVID-19 [8].

\section{KONFLIKT INTERESÓW}

Autorzy nie zgłaszają konfliktu interesów. 


\section{References}

\section{Piśmiennictwo}

1. Hageman J.R.: The coronavirus disease 2019 (COVID-19). Pediatr Ann 2020, 49, e99-e100.

2. Chen Y., Pradhan S., Xue S.: What are we doing in the dermatology outpatient department amidst the raging of the 2019 novel coronavirus? J Am Acad Dermatol 2020, 82, 1034.

3. Litchman G.H., Rigel D.S.: The immediate impact of COVID-19 on US dermatology practices. J Am Acad Dermatol 2020, 83, 685-686.

4. Türsen Ü., Türsen B., Lotti T.: Coronavirus-days in dermatology. Dermatol Ther 2020, 33, e13438.

5. Lan J., Song Z., Miao X., Li H., Li Y., Dong L., et al.: Skin damage among health care workers managing coronavirus disease-2019. J Am Acad Dermatol 2020, 82, 1215-1216.

6. Yan Y., Chen H., Chen L., Cheng B., Diao P., Dong L., et al.: Consensus of Chinese experts on protection of skin and mucous membrane barrier for health-care workers fighting against coronavirus disease 2019. Dermatol Ther 2020, e13310. doi: 10.1111/ dth.13310.

7. Bauer A., Rönsch H., Elsner P., Dittmar D., Bennett C., Schuttelaar M.L.A., et al.: Interventions for preventing occupational irritant hand dermatitis. Cochrane Database Syst Rev 2018, 4, CD004414.

8. Paolino G., Mercuri S.R., Bearzi P., Mattozzi C.: Systemic immunobiological, immunosuppressant and oncologic agents for the treatment of dermatologic diseases during the SARS-CoV-2 (COVID19) pandemic emergency: a quick review for a quick consultation. Dermatol Ther 2020 May 8:e13537.

9. Galimberti F., McBride J., Cronin M., Li Y., Fox J., Abrouk M., et al.:. Evidenced-based best practice advice for patients treated with systemic immunosuppressants in relation to COVID-19. Clin Dermatol 2020, 38, 775-780.

Received: 12.08 .2020

Accepted: 11.11 .2020

Otrzymano: $12.08 .2020 \mathrm{r}$.

Zaakceptowano: $11.11 .2020 \mathrm{r}$. 